\title{
Agronomical and phytochemical investigation of Hyssopus officinalis
}

\author{
Bertalan Galambosi, Katerina P. Svoboda, Stanley G. Deans \\ and EVA HETHELYI
}

Galambosi, B., Svoboda, K.P., Deans, S.G. \& Hethelyı, E. 1993. Agronomical and phytochemical investigation of Hyssopus officinalis. Agric. Sci. Finl. 2: 293-302. (Agric. Res. Centre of Finland, South Savo Res. Sta., FIN-50600 Mikkeli, Finland, Aromatic and Medicinal Plant Group, Scott. Agric. Coll., Auchincruive, Scotland, UK and Res. Inst. Medicinal Plants, H-2011 Budakalasz, Hungary.)

Hyssop (Hyssopus officinalis L.) obtained from various commercial sources was grown for three years (1990-1992) in Finland. Yield characteristics, flcwer colour, volatile oil content/composition and its antimicrobial quality were studied. For comparison, Scottish-grown hyssop was included in oil and quality determinations. The description of the flower colour given by the seed firms was not a reliable indicator of the true colour in many cases. Oil yield was satisfactory and oil composition was rather uniform. Only one different chemotype was identified, this was derived from a Romanian seed source. There was considerable variation in herb yield between plants from different sources. The total fresh herb yield was $0.5-3.2 \mathrm{~kg} / \mathrm{m}^{2}$, the dry leaf yield was $67-326 \mathrm{~g} / \mathrm{m}^{2}$. Seed germination was satisfactory (76-99\%), offering opportunities for seed production of varieties with different characteristics.

Key words: Hyssopus officinalis, yield characteristics, seed quality, volatile oil content/composition, antibacterial properties

\section{Introduction}

Due to increasing interest in growing and using herbs in the northern parts of Europe, several research projects have been carried out in both Finland and Scotland during the last few years (GALAMBOSI et al. 1991, HAY et al. 1988, SvoBodA et al. 1990). Hyssop was one of the 40 herb species which were studied in a five year research project at Puumala, Southern Finland. This species proved to be both cold and frost tolerant with good dry matter yield and volatile oil content (GALAmBosi et al. 1989). The flowering tops and leaves of hyssop are used as flavours in the food and drink industry and in various cosmetic products (GENDERS 1980). It is also a traditional medicinal plant (BONAR 1985, FLEISCHER and FLEISCHER 1988), an excellent plant for attracting bees (HOOPER 1984) and an attractive garden ornamental (SANECKI 1985). Several types, differing in flower colour, flowering time and leaf shape are available commercially: alba (white flowers), grandiflora (large flowers), rosea (rose flowers) and rubia (red flowers) (SIMON et al. 1984). The seed samples are often mixed and it is quite difficult to obtain uniform plant populations for specific requirements, such as decorative flower production, honey bee forage production, high volatile oil yield and uniform quantitative oil composition.

The objective of this study was to test in Finland 13 different seed samples of various geographical origins for the variability of colour, growth, fresh 
and dry matter yield and seed production. For comparison, hyssop grown in Scotland was included in oil yield and quality determinations. In addition, the antimicrobial activity of the oil was tested against a group of 25 bacterial species.

\section{Material and methods}

\section{Growth conditions}

The plants were grown at South Savo Research Station, Mikkeli, Finland (grid reference $61^{\circ} 44^{\prime} \mathrm{N}$, $\left.27^{\circ} 18^{\prime} \mathrm{E}\right)$ during 1990-1992 and in the herb garden of the Scottish Agricultural College $\left(55^{\circ} 28 \mathrm{~N}, 4^{\circ}\right.$ $33^{\circ} \mathrm{W}$ ) during 1990-1992. The meteorological data for Mikkeli are presented in Figures 1 and 2. The origin of seed samples and the colour of the plants grown in Mikkeli are given in Table 1. Hyssop seeds Nos. 14-21 were obtained from Poyntzfield Nursery, Black Isle, Scotland, and were of French origin. The seeds were sown in pots $(5 \times 5 \mathrm{~cm}$ diameter) filled with fine peat on 26 April 1990. The pots were kept in a plastic greenhouse and the seedlings transplanted to the field on 8 June. One year old plants of the varieties Nos. 2, 3 and 4 were transplanted into experimental plots from Puumala on 4 June 1990. The density of planting was four plants per $\mathrm{m}^{2}$.

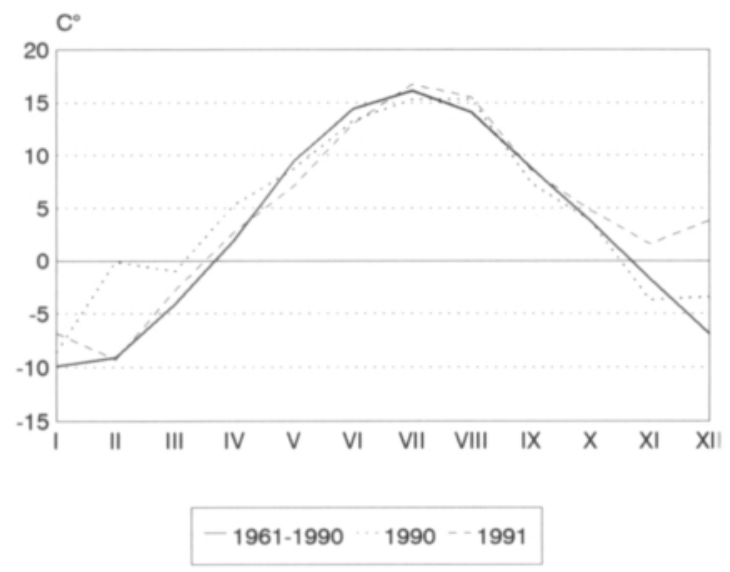

Fig. 1. The monthly mean temperature during the experimental period Mikkeli.

\section{Cultivation and fertilization}

The soil in Finland was a stony till, $\mathrm{pH}$ 6.2. The experimental plots were fertilized before planting (N 35, P 120 and K $70 \mathrm{~kg} / \mathrm{ha}$ ) with further N (15 $\mathrm{kg} / \mathrm{ha}$ ) three weeks after planting. The same basic fertilizer mixture was applied at the beginning of the second year. The plants were irrigated twice during the first and once during the second growing season.

In Scotland, the experimental plots were located on a sandy loam soil of pH 5.8. No artificial fertilizers were applied. Farmyard manure was added each autumn. Nos. 19-21 were grown in a polytunnel throughout the whole season.

\section{Harvesting and drying}

In Finland, plants were harvested each summer in August, during the full flowering period. From each of the varieties 10 plants were cut and the following characteristics were determined: colour of flowers, plant height, fresh and dry weight, and leaf:stem ratio. In Scotland, individual, well-established 3 year old plants were collected randomly during the full flowering period. Fresh samples were dried at $35^{\circ} \mathrm{C}$ and the stems were separated from the leaves through a $3 \mathrm{~mm}$ diameter screen.

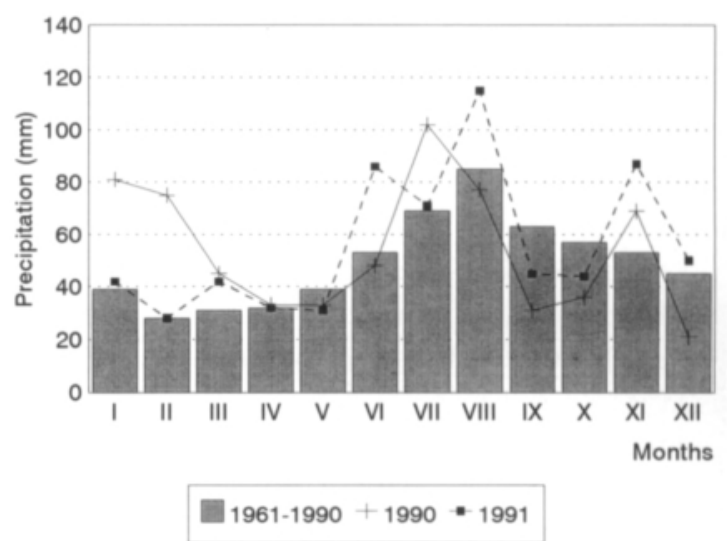

Fig. 2. The monthly precipitation during experimental period Mikkeli. 
Table 1. Identity and origin of varieties/populations of hyssop grown in Mikkeli.

\begin{tabular}{|c|c|c|c|c|c|}
\hline \multirow[t]{2}{*}{ No } & \multirow[t]{2}{*}{ Variety/population } & \multirow{2}{*}{$\begin{array}{l}\text { Year of } \\
\text { acquisi- } \\
\text { tion }\end{array}$} & \multirow{2}{*}{ Origin of seed } & \multicolumn{2}{|c|}{ Flower colour } \\
\hline & & & & $\begin{array}{l}\text { Expected/ } \\
\text { advertised }\end{array}$ & Observed \\
\hline 1 & Hyssopus officinalis 'Kekviragu' & 1984 & Hungaroseed, Budapest, Hungary & Blue & Mixed colours \\
\hline 2 & Hyssopus officinalis, Pink hyssop & 1989 & Suffolk Herbs, Suffolk, England & Pink & Pink \\
\hline 3 & Hyssopus officinalis & 1988 & $\begin{array}{l}\text { Institute de Medicine } \mathrm{Si} \\
\text { Farmacia Tirgu Mures, Romania }\end{array}$ & - & Red \\
\hline 4 & Hyssopus officinalis, White Hyssop & 1989 & Suffolk Herbs, Suffolk, England & White & White \\
\hline 5 & Hyssopus officinalis & 1989 & Piikio, Pukkila Manor, Finland & - & Blue \\
\hline 6 & Hyssopus officinalis (Azob, Holy Herb) & 1989 & Suffolk Herbs, Suffolk, England & Blue, white, pink & Blue \\
\hline 7 & Hyssopus officinalis ssp aristatus & 1989 & $\begin{array}{l}\text { Hortus Botanicus Bernensis, } \\
\text { Bern, Switzerland }\end{array}$ & - & Blue \\
\hline 8 & Hyssopus officinalis (from commerce) & 1990 & Hortus, (origin unkown) & Blue & Blue \\
\hline 9 & Hyssopus officinalis (from commerce) & 1990 & EKA (AL-GRO), Finland & Blue, violet & Blue \\
\hline 10 & Hyssopus officinalis (from commerce) & 1990 & $\begin{array}{l}\text { Vesan Siemenliike Oy, } \\
\text { (Samen Mauser), Finland }\end{array}$ & Pink & Blue \\
\hline 11 & Hyssopus officinalis (from commerce) & 1990 & $\begin{array}{l}\text { Maatalouskesko (Samen Mauser), } \\
\text { Finland }\end{array}$ & Pink & Blue \\
\hline 12 & Hyssopus officinalis (from commerce) & 1990 & Siemen Oy, (origin unkown) & Blue & Mixed \\
\hline 13 & Hyssopus officinalis (from commerce) & 1990 & Sokos (Hammenhogs) Finland & Blue & Mixed \\
\hline
\end{tabular}

\section{Germination test}

Five plants from each variety were grown for seeds. The seeds were harvested at the end of the vegetation period (25 September 1990, 10 September 1991, 24 September 1992). The hand cut plants were dried at room temperature $\left(18-22^{\circ} \mathrm{C}\right)$ and the seeds were crushed either by hand, or by using an experimental harvester (Hege $125 \mathrm{C}$, Germany). The germination tests were carried out each year 3 months after harvesting, using the top paper method in $9 \mathrm{~mm}$ Petri dishes, at $20-23^{\circ} \mathrm{C}$ day and $17-19^{\circ} \mathrm{C}$ night temperature, with $4 \times 50$ seeds per variety.

\section{Distillation of oil}

Dried leaves and flowering tops were steam distilled for $2 \mathrm{~h}$ using British Pharmacopoeia distillation apparatus (BSI 1985). The quantity of oil obtained was measured and the oil was then transferred to glass vials with Teflon-lined caps and stored in a refrigerator at -2 to $6^{\circ} \mathrm{C}$ until analysed by GC.

\section{GC analysis of oil}

GC was carried out using a United Technologies Packard 439 GC connected to a Hewlett Packard Integrator 3390A. The following operating conditions were used: Carbowax $20 \mathrm{M}$ column, $25 \mathrm{~m} \mathrm{x}$ $0.32 \mathrm{~mm}$; carrier gas $\mathrm{N}_{2}$; injection temperature $250^{\circ} \mathrm{C}$; flame ionisation detector temperature $250^{\circ} \mathrm{C}$; oven temperature initially $50^{\circ} \mathrm{C}$, rising to $200^{\circ} \mathrm{C}$ at $5^{\circ} \mathrm{C} / \mathrm{min}$; sample size $0.2 \mathrm{l}$; splitter 1:100. Standard oil components for comparison were obtained from Roth (Karlsruhe, Germany).

\section{Antibacterial properties of volatile oils}

For the determination of antibacterial properties of the volatile oil from hyssop, wells were punched in pre-seeded Isosensitest agar plates and to each well was added $15 \mathrm{ml}$ volatile oil (DEANS and RITCHIE 1987). This was allowed to diffuse into the agar prior to incubation at $25^{\circ} \mathrm{C}$ for $48 \mathrm{~h}$, after which zones of growth inhibition were measured with vernier calipers. Three wells per plate were made and two replicate plates tested per organism. 
Table 2. Plant height and weight of hyssop varieties at different ages. (Mikkeli, 1990-1991).

\begin{tabular}{|c|c|c|c|c|c|c|c|c|}
\hline \multirow[t]{2}{*}{ Variety/population } & \multicolumn{4}{|c|}{ Plant height $(\mathrm{cm})$} & \multicolumn{4}{|c|}{ Fresh weight (g/plant) } \\
\hline & \multicolumn{2}{|c|}{1990} & \multicolumn{2}{|c|}{1991} & \multicolumn{2}{|c|}{1990} & \multicolumn{2}{|c|}{1991} \\
\hline \multirow[t]{2}{*}{ Seedling transplants: } & \multicolumn{2}{|c|}{ Year 1} & \multicolumn{2}{|c|}{ Year 2} & \multicolumn{2}{|c|}{ Year 1} & \multicolumn{2}{|c|}{ Year 2} \\
\hline & $\mathrm{x}$ & s & $\mathrm{x}$ & $\mathbf{s}$ & $\mathrm{x}$ & s & $\mathrm{x}$ & s \\
\hline 1. Mixed hyssop & 49 & 3.7 & 53 & 4.1 & 282 & 51 & 369 & 162 \\
\hline 2. Pink hyssop & 58 & 6.2 & 65 & 4.5 & 393 & 107 & 434 & 140 \\
\hline 3. Red hyssop & 42 & 2.7 & 47 & 2.4 & 128 & 62 & 286 & 93 \\
\hline 4. White hyssop & 63 & 3.9 & 75 & 4.5 & 310 & 88 & 541 & 151 \\
\hline 5. Blue hyssop & 55 & 4.2 & 59 & 4.9 & 455 & 69 & 434 & 119 \\
\hline 6. Azob hyssop & 62 & 4.7 & 69 & 5.8 & 486 & 76 & 693 & 239 \\
\hline 7. H.o. ssp. aristatus & 62 & 5.2 & 63 & 3.8 & 660 & 99 & 452 & 197 \\
\hline 8. Commercial hyssop & 46 & 3.9 & 54 & 3.8 & 244 & 45 & 299 & 164 \\
\hline 9. Commercial hyssop & 44 & 3.1 & 52 & 4.1 & 182 & 41 & 283 & 89 \\
\hline 10. Commercial hyssop & 48 & 4.6 & 56 & 7.5 & 213 & 64 & 219 & 82 \\
\hline 11. Commercial hyssop & 46 & 3.4 & 56 & 4.1 & 195 & 46 & 319 & 114 \\
\hline 12. Commercial hyssop & 49 & 9.4 & 60 & 5.5 & 255 & 76 & 369 & 164 \\
\hline \multirow{2}{*}{$\begin{array}{l}\text { 13. Commercial hyssop } \\
\text { Mean: }\end{array}$} & 47 & 3.2 & 53 & 7.5 & 270 & 68 & 284 & 89 \\
\hline & 48 & & 59 & & 313 & & 386 & \\
\hline One year old transplants & \multicolumn{2}{|c|}{ Year 2} & \multicolumn{2}{|c|}{ Year 3} & \multicolumn{2}{|c|}{ Year 2} & \multicolumn{2}{|c|}{ Year 3} \\
\hline 2. Pink hyssop & 58 & 6.8 & 66 & 5.8 & 455 & 223 & 556 & 195 \\
\hline 3. Red hyssop & 42 & 4.8 & 58 & 5.1 & 292 & 70 & 344 & 97 \\
\hline 4. White hyssop & 65 & 5.7 & 76 & 3.8 & 430 & 84 & 630 & 196 \\
\hline 6. Azob hyssop & 65 & 4.3 & 68 & 2.6 & 452 & 110 & 812 & 211 \\
\hline Mean: & 58 & & 67 & & 407 & & 586 & \\
\hline
\end{tabular}

\section{Results and discussion}

\section{Variation in colour of hyssop flowers}

Of the 13 seed samples grown in Mikkeli, two had no colour indication. No. 3 proved to be a red and No. 7 a blue coloured hyssop (Table 1).

Six samples had the colour as advertised on the commercial packing or as the original mother plant. The colour of the flowers of five samples was different from the advertised description: Nos 1, 10, 11,12 and 13. Since all seeds were from commercial sources, the quality control clearly needs to be improved.

\section{Growth characteristics}

The meteorological conditions during the experimental years did not differ significantly from the long term average (Figs. 1-2). Frost damage was observed only in acquistion No. 7, which resulted in lower plant weight during the second growing season (Table 2). This indicates the frost tolerance of hyssop (GALAMBOSI et al. 1989). The lower precipitation during September was advantageous for seed ripening.

The differences in the plant height and weight during the consecutive seasons were clear: the average height of the one year old plants was $48 \mathrm{~cm}$, of two year old plants $58-59 \mathrm{~cm}$ and of three year old plants $67 \mathrm{~cm}$ (Table 2). The smallest variety was No. 3 (Romania) reaching 42 and $47 \mathrm{~cm}$ during the first and second year respectively. This variety had a typically compact habit. The tallest varieties were consistently Nos. 4, 6 and 7, reaching $62-75 \mathrm{~cm}$ of height. However, these plants were loose in habit and the heavy rains often caused lodging. 
Table 3. Total fresh weight yield and dry leaf yield of hyssop varieties at different ages (Mikkeli, 1990-1991).

\begin{tabular}{|c|c|c|c|c|c|c|}
\hline \multirow[t]{2}{*}{ Yield } & \multirow[t]{2}{*}{ Age } & \multicolumn{5}{|c|}{ Varieties } \\
\hline & & $\begin{array}{l}\text { 1. Mixed } \\
\text { hyssop }\end{array}$ & $\begin{array}{l}\text { 2. Pink } \\
\text { hyssop }\end{array}$ & $\begin{array}{l}\text { 3. Red } \\
\text { hyssop }\end{array}$ & $\begin{array}{l}\text { 4. White } \\
\text { hyssop }\end{array}$ & $\begin{array}{l}\text { 6. Azob } \\
\text { hyssop }\end{array}$ \\
\hline \multirow[t]{3}{*}{ Total fresh $\left(\mathrm{kg} / \mathrm{m}^{2}\right)$} & 1 year old & 1.12 & 1.57 & 0.51 & 1.24 & 1.94 \\
\hline & 2 year old & 1.58 & 1.73 & 1.14 & 2.16 & 2.77 \\
\hline & 3 year old & 2.23 & 2.22 & 1.37 & 2.52 & 3.24 \\
\hline \multirow[t]{3}{*}{ Dry leaf $\left(\mathrm{kg} / \mathrm{m}^{2}\right)$} & 1 year old & 0.16 & 0.18 & 0.06 & 0.14 & 0.26 \\
\hline & 2 year old & 0.21 & 0.19 & 0.16 & 0.22 & 0.30 \\
\hline & 3 year old & 0.26 & 0.25 & 0.19 & 0.25 & 0.36 \\
\hline
\end{tabular}

\section{Herb yield}

The results of the plant weights presented in Table 2 show significant variability between the sources. The average weight of plants grown from seeds was $313 \mathrm{~g}$ and $386 \mathrm{~g}$ during the first and second year, respectively. The transplanted one year old plants were significantly heavier during the second and third season, reaching $407 \mathrm{~g}$ and $586 \mathrm{~g}$ of fresh weight per plant, respectively.

The total fresh weight yield varied between 0.5 and $3.2 \mathrm{~kg} / \mathrm{m}^{2}$ depending on plant age (Table 3 ). The lowest yield was obtained from the variety No. 3 , producing 0.5 (first year), 1.1 (second year) and 1.3 (third year) $\mathrm{kg} / \mathrm{m}^{2}$ fresh weight. The highest yields were derived from No. 6, producing 1.9, 2.7 and $3.2 \mathrm{~kg} / \mathrm{m}^{2}$ of fresh weight throughout the three seasons.

The leaf dry weight (Table 3 ) varied from 67 to $367 \mathrm{~g} / \mathrm{m}^{2}$. Consistent with plant vigour and development, the lowest yield was obtained from the variety No. 3 and the highest yield from the variety No. 6, but the differences were less pronounced than those of fresh yield. The dry matter content varied from $22-30 \%$. The leaf:stem ratio was about $1: 1$, the first year plants having less, the second and third year old plants having more stems (Table 4). The marketable leaf and flower dry weight yield calculated from the dry matter content and leaf:stem ratio was $10-14 \%$ of the total harvested fresh yield. The lowest dry weight yield $(10 \%)$ was measured in tall, loose, pink and white varieties, due to their high stem and twigs contents.
Table 4. Dry matter content and leaf/stem ratio in hyssop varieties at different ages (Mikkeli 1990-1991).

\begin{tabular}{lccccc}
\hline Variety/population & $\begin{array}{c}\text { Dry matter } \\
\text { content }(\%)\end{array}$ & & \multicolumn{2}{c}{$\begin{array}{c}\text { Leaf/stem } \\
\text { ratio }(\%)\end{array}$} \\
\cline { 2 - 3 } \cline { 6 - 7 } & 1990 & 1991 & & 1990 & 1991 \\
\hline Seedling transplants: & Year 1 & Year 2 & & Year 1 & Year 2 \\
1. Mixed hyssop & 24.8 & 23.5 & & $58: 42$ & $57: 43$ \\
2. Pink hyssop & 22.6 & 25.0 & & $52: 48$ & $44: 56$ \\
3. Red hyssop & 23.2 & 25.5 & & $56: 44$ & $57: 43$ \\
4. White hyssop & 21.9 & 25.4 & & $53: 47$ & $40: 60$ \\
5. Blue hyssop & 22.5 & 25.7 & & $57: 43$ & $55: 45$ \\
6. Azob hyssop & 22.7 & 23.6 & & $59: 41$ & $47: 53$ \\
7. H.o. ssp. aristatus & 23.3 & 29.8 & & - & - \\
8. Commercial hyssop & 25.2 & 23.1 & & $55: 45$ & $43: 57$ \\
9. Commercial hyssop & 23.9 & 25.9 & & $55: 45$ & $43: 57$ \\
10. Commercial hyssop & 23.9 & 22.8 & & $61: 39$ & $45: 55$ \\
11. Commercial hyssop & 22.7 & 25.0 & & $55: 45$ & $45: 55$ \\
12. Commercial hyssop & 25.0 & 24.7 & & $54: 46$ & $46: 54$ \\
13. Commercial hyssop & 21.6 & 24.7 & & $62: 38$ & $46: 52$ \\
Mean: & 23.3 & 25.0 & & $56: 44$ & $48: 52$
\end{tabular}

One year old

transplants:

2. Pink hyssop

Year 2 Year 3 Year 2 Year 3

3. Red hyssop

4. White hyssop

6. Azob hyssop

$23.3 \quad 24.7 \quad 51: 49 \quad 46: 54$

$24.9 \quad 24.8 \quad 64: 36 \quad 56: 44$

$23.8 \quad 25.4 \quad 49: 51 \quad 39: 61$

$22.7 \quad 25.1 \quad 59: 41 \quad 45: 55$

Mean: $23.7 \quad 25.0 \quad 56: 44 \quad 47: 53$

Figures are means of two replications.

\section{Seed quality}

The germination tests showed that the hyssop varieties were consistently of good seed quality. The 
Table 5. Seed germination and thousand seed weight (TSW) of hyssop varieties (Mikkeli, 1991).

\begin{tabular}{lcccccc}
\hline Variety & \multicolumn{2}{c}{$\begin{array}{c}\text { Germination } \% \\
\text { harvested by }\end{array}$} & & \multicolumn{2}{c}{$\begin{array}{c}\text { TSW (g) } \\
\text { harvested by }\end{array}$} \\
\cline { 2 - 3 } \cline { 6 - 7 } & hand & combine & & hand & combine \\
\hline 1. Mixed hyssop & 84 & 73 & & 1.100 & 0.983 \\
2. Pink hyssop & 95 & 88 & & 0.783 & 0.750 \\
3. Red hyssop & 94 & 59 & & 1.000 & 0.983 \\
4. White hyssop & 78 & 74 & & 1.000 & 1.016 \\
5. Blue hyssop & 97 & 90 & & 1.000 & 0.916 \\
6. Azob hyssop & 97 & 81 & & 1.050 & 1.016 \\
7. ssp. aristatus & 93 & 90 & & 1.050 & 0.983 \\
\multicolumn{1}{c}{ Mean: } & 91 & 79 & & 0.997 & 0.949 \\
\hline
\end{tabular}

Table 6. Seed germination of hand-harvested hyssop varieties (Mikkeli, 1990-1992).

\begin{tabular}{lrccc}
\hline Variety & \multicolumn{4}{c}{ Germination \% } \\
\cline { 2 - 5 } & 1990 & 1991 & 1992 & Mean \\
\hline 1. Mixed hyssop & 84 & 84 & 93 & 87 \\
2. Pink hyssop & 89 & 95 & 82 & 89 \\
3. Red hyssop & 99 & 94 & 70 & 88 \\
4. White hyssop & 80 & 78 & 70 & 76 \\
5. Blue hyssop & - & 97 & 80 & 88 \\
6. Azob hyssop & 97 & 97 & 84 & 93 \\
7. ssp. aristatus & 91 & 93 & 88 & 91 \\
\multicolumn{1}{c}{ Mean: } & 90 & 91 & 81 & 87 \\
\hline
\end{tabular}

average germination capacity of seeds was $87 \%$ (Tables 5 and 6). The lowest results were achieved by white hyssop $(76 \%)$, being a late flowering type. The seed production could be easily mechanized. There were $10-15 \%$ differences in the germination of the hand crushed and mechanically crushed seed. The differences could be eliminated by optimization of the harvest times. The average thousand seed weight of hyssop varieties was $1.0 \mathrm{~g}$, ranging between $0.75 \mathrm{~g}$ and $1.1 \mathrm{~g}$ (Table 5). The pink hyssop (No. 2) had the lowest seed weight.

\section{Quantitative variations in the volatile oil yield}

Volatile oil contents of leaves and flowering tops varied for 0.4 to $1.4 \%$ (Table 7 ). Blue varieties grown in Finland had a range of oil yield: 0.7$1.08 \%$. The blue coloured hyssop No. 7 had the highest oil content (1.36\%). Mixed coloured varieties had a range of $0.94-1.2 \%$, white $0.6-0.7 \%$, pink and red $0.6-0.8 \%$. There were no differences between one and two year old plants.

Oil contents of Scottish-grown blue coloured plants showed values of $0.4-1.4 \%$. There was no difference between plants grown in the open field or in the polytunnel. No clear pattern was observed in the oil content fluctuations, but this high variability within the individual plants suggests the possibility of improving the oil yield (0.3-1.6\%) (JOULAIN and Ragault 1976, Hilal et al. 1978, MechraZ et al. 1989). The leaf oil content from samples grown both in Finland and in Scotland was above average. KHODZIMATOC and RAMAZANOVA (1975) report unusually high oil contents: about $1.6 \%$ from red, $2.2 \%$ from blue and $3.7 \%$ from white varieties. In our experimental plants, these levels of oil content were not realized, neither were there any significant differences in oil yield between various types of colour, although the relatively low oil contents of the white and pink varieties have to be noted.

Maximum oil contents were found during the full flowering period, with stems containing a negligible amount of oil (KAPELEV 1986, TIMCHUK et al. 1986). The results emphasize the importance of selection and of fertilizer use for improved types in aromatic plant species (SvOBODA et al. 1990). Hyssop can be an appropriate crop for the northern areas, with very good quality and quantity of the final product.

\section{Quantitative variations in the volatile oil}

The volatile oil composition showed similar results for both Finnish and Scottish material, with one exception: red hyssop originating from Romania (Table 7). This oil had significantly higher amounts of germacrene-D (22-23\%) and pinocarvone (26$28 \%$ ) compared with the other samples. Iso-pinocamphone, pinocamphone, $\beta$-pinene, pinocarvone, germacrene D and 1,8-cineol were the main components of the oil and accounted for $75-85 \%$ of total 
Table 7. Main components of hyssop oil derived from whole plants grown in Finland (F) and Scotland (S).

\begin{tabular}{|c|c|c|c|c|c|c|c|c|}
\hline Flower colour & $\begin{array}{l}\text { Variety/ } \\
\text { population }\end{array}$ & $\begin{array}{c}\text { Volatile oil } \\
\text { content } \\
(\% \mathrm{v} / \mathrm{w})\end{array}$ & $\begin{array}{l}\text { Pino- } \\
\text { camphone }\end{array}$ & $\begin{array}{l}\text { Iso-pino- } \\
\text { camphone } \\
\text { (Figur }\end{array}$ & $\begin{array}{l}\text { Germa- } \\
\text { crene D } \\
\text { are } \% \text { of }\end{array}$ & $\begin{array}{l}\text { Pino- } \\
\text { carvone } \\
\text { l oil) }\end{array}$ & $\beta$-Pinene & 1,8-Cineol \\
\hline \multirow[t]{16}{*}{ Blue: } & $5 a(F)$ & 1.00 & 20.3 & 33.3 & 11.0 & 5.5 & 7.1 & 4.3 \\
\hline & 6a (F) & 1.00 & 9.4 & 42.6 & 11.7 & 8.1 & 3.5 & 7.1 \\
\hline & $6 \mathrm{~b}(\mathrm{~F})$ & 0.83 & 20.9 & 25.6 & 7.9 & 4.0 & 10.1 & 7.2 \\
\hline & $7 a(F)$ & 1.36 & 19.9 & 35.1 & 17.0 & 10.3 & 2.2 & 1.8 \\
\hline & $8 \mathrm{a}(\mathrm{F})$ & 0.73 & 17.3 & 33.5 & 11.1 & 9.3 & 4.3 & 3.1 \\
\hline & $9 \mathrm{a}(\mathrm{F})$ & 1.03 & 11.9 & 38.3 & 11.1 & 7.9 & 4.1 & 4.2 \\
\hline & 10a (F) & 1.08 & 19.4 & 30.2 & 11.0 & 7.7 & 7.2 & 5.0 \\
\hline & $11 \mathrm{a}(\mathrm{F})$ & 1.07 & 14.4 & 36.2 & 12.5 & 9.5 & 3.5 & 3.6 \\
\hline & $14 \mathrm{c}(\mathrm{S})$ & 0.40 & 37.5 & 18.0 & 13.1 & 5.1 & 7.1 & 1.2 \\
\hline & $15 \mathrm{c}(\mathrm{S})$ & 0.50 & 36.6 & 17.7 & 13.3 & 4.9 & 7.8 & 1.2 \\
\hline & $16 \mathrm{c}(\mathrm{S})$ & 0.50 & 46.0 & 15.6 & 13.1 & 8.0 & 3.7 & 1.4 \\
\hline & $17 \mathrm{c}(\mathrm{S})$ & 1.40 & 46.3 & 15.8 & 11.9 & 8.2 & 4.1 & 1.3 \\
\hline & $18 \mathrm{c}(\mathrm{S})$ & 1.40 & 0.7 & 53.8 & 14.2 & 6.1 & 1.5 & 0.7 \\
\hline & 19c (S) & 1.00 & 0.9 & 52.8 & 11.9 & 6.1 & 1.7 & 0.7 \\
\hline & $20 \mathrm{c}(\mathrm{S})$ & 0.50 & 24.0 & 36.8 & 13.8 & 4.0 & 3.8 & 0.9 \\
\hline & $21 \mathrm{c}(\mathrm{S})$ & 0.50 & 24.2 & 37.0 & 14.2 & 4.0 & 3.4 & 1.0 \\
\hline \multirow[t]{3}{*}{ Mixed: } & 1a (F) & 1.15 & 26.0 & 19.0 & 17.7 & 12.0 & 4.2 & 2.7 \\
\hline & 12a (F) & 1.19 & 11.0 & 34.4 & 15.4 & 13.1 & 2.8 & 3.5 \\
\hline & 13a (F) & 0.94 & 17.2 & 31.4 & 11.6 & 12.8 & 4.0 & 2.8 \\
\hline \multirow[t]{2}{*}{ White: } & 4a (F) & 0.62 & $\#$ & 52.7 & 14.9 & 2.5 & 6.9 & 1.2 \\
\hline & $4 b(F)$ & 0.74 & 47.4 & 2.4 & 16.2 & 2.4 & 9.0 & 1.3 \\
\hline \multirow[t]{4}{*}{ Pink, Red: } & $2 a(F)$ & 0.74 & 0.9 & 53.4 & 16.3 & 1.5 & 4.7 & 1.8 \\
\hline & $2 \mathrm{~b}(\mathrm{~F})$ & 0.82 & 0.6 & 50.1 & 14.5 & 1.6 & 7.3 & 0.7 \\
\hline & 3a (F) & 0.67 & 1.4 & 15.1 & 23.2 & 27.9 & 5.9 & 4.5 \\
\hline & 3b (F) & 0.60 & 1.3 & 13.1 & 22.3 & 25.6 & 9.4 & 4.9 \\
\hline
\end{tabular}

$\mathrm{a}=$ one year old plants; $\mathrm{b}=$ two year old plants; $\mathrm{c}=$ three year old plants. $\#=$ trace amounts.

oil. Two major components, pinocamphone and iso-pinocamphone constituted about $50 \%$ of total oil and their representative proportions varied in a manner which could not be explained in the existing experiments. Variations in plants derived from different geographical origins emphasize the importance of further selection studies.

Our results are in agreement with earlier reports (LAWRENCE 1980, STEINMETZ et al. 1980, LAWRENCE, 1984, TiMCHUK et al. 1986, GALAMBOSI et al. 1989, MECHRAZ et al. 1989, SCHULZ and STAHL 1991). Only one reference (KHODZHIMATOV and RAMAZANOVA 1975) mentioned different hyssop chemotypes, with high amounts of 1,8-cineol, li- nalool, $\alpha$-terpineol, $\alpha$-terpinyl acetate and bornyl acetate (identified by GC analysis). It is possible that hyssop collected in the Taskent area showed intraspecific chemical differences. Pinocamphone, iso-pinocamphone, camphor and thujone are responsible for the toxicity of the oil (STEINMETZ et al. 1980). The experiments were conducted with rats and both the oil and individual components caused nerve and muscle damage, resulting in epilepsy. The above mentioned monoterpenes are very volatile and their chemical structure may change under different environmental conditions and through postharvest handling. These facts could partially explain the variability of individual oil components 
Table 8. Antibacterial properties of hyssop volatile oil (inhibition zone diameter in $\mathrm{mm}$; diameter of well, $4 \mathrm{~mm}$, included).

\begin{tabular}{|c|c|c|c|c|c|c|c|c|c|c|c|c|c|c|c|c|c|}
\hline \multirow[t]{2}{*}{ Organism } & \multicolumn{17}{|c|}{ Hyssop strain number } \\
\hline & 1 & 2 & 3 & 4 & 5 & 6 & 7 & 8 & 9 & 10 & 11 & 12 & 13 & 14 & 15 & 16 & 17 \\
\hline A & 9.4 & 9.5 & 8.9 & 9.8 & 9.0 & 9.4 & 8.4 & 11.4 & 14.5 & 8.4 & 13.0 & 9.8 & 11.0 & 12.3 & 8.8 & 12.0 & 8.4 \\
\hline B & 5.3 & 4.9 & 5.0 & 6.4 & 6.4 & 5.7 & 4.9 & 4.7 & 5.2 & 5.1 & 5.6 & 4.8 & 5.3 & 5.2 & 6.1 & 5.4 & 4.7 \\
\hline $\mathrm{C}$ & 4.0 & 4.0 & 4.0 & 4.0 & 4.0 & 4.0 & 4.0 & 4.0 & 4.0 & 4.0 & 4.0 & 4.0 & 4.0 & 4.0 & 4.0 & 4.0 & 4.0 \\
\hline D & 4.0 & 4.0 & 4.0 & 4.0 & 4.0 & 4.0 & 4.0 & 4.0 & 4.0 & 4.0 & 4.0 & 4.0 & 4.0 & 4.0 & 4.0 & 4.0 & 4.0 \\
\hline $\mathrm{E}$ & 4.0 & 4.0 & 4.0 & 4.0 & 4.0 & 4.0 & 4.0 & 4.0 & 4.0 & 4.0 & 4.0 & 4.0 & 4.0 & 4.0 & 4.0 & 4.0 & 4.0 \\
\hline $\mathrm{F}$ & 11.0 & 11.6 & 9.3 & 8.7 & 8.0 & 10.0 & 10.0 & 9.4 & 8.2 & 9.2 & 8.6 & 9.0 & 8.1 & 11.0 & 8.6 & 9.4 & 7.0 \\
\hline G & 5.6 & 6.1 & 5.6 & 5.4 & 5.5 & 5.8 & 6.1 & 5.3 & 5.9 & 4.0 & 5.4 & 6.4 & 6.1 & 5.8 & 4.0 & 4.0 & 5.2 \\
\hline $\mathrm{H}$ & 4.0 & 4.0 & 4.0 & 4.0 & 4.0 & 4.0 & 4.0 & 4.0 & 4.0 & 4.0 & 4.0 & 4.0 & 4.0 & 4.0 & 4.0 & 4.0 & 4.0 \\
\hline 1 & 4.0 & 4.0 & 4.0 & 4.0 & 4.0 & 4.0 & 4.0 & 10.2 & 10.6 & 10.0 & 12.6 & 14.5 & 10.0 & 8.9 & 10.6 & 11.2 & 7.8 \\
\hline $\mathbf{J}$ & 4.0 & 4.0 & 4.0 & 4.0 & 4.0 & 4.0 & 4.0 & 4.0 & 4.0 & 4.0 & 4.0 & 4.0 & 4.0 & 4.0 & 4.0 & 4.0 & 4.0 \\
\hline K & 5.8 & 4.0 & 4.0 & 5.6 & 4.8 & 4.9 & 4.0 & 5.2 & 5.5 & 4.0 & 7.5 & 4.0 & 5.6 & 5.8 & 6.2 & 6.0 & 4.0 \\
\hline L & 4.0 & 4.0 & 4.0 & 4.0 & 4.0 & 4.0 & 4.0 & 4.0 & 4.0 & 4.0 & 4.0 & 4.0 & 4.0 & 4.0 & 4.0 & 4.0 & 4.0 \\
\hline M & 4.0 & 4.0 & 4.0 & 4.0 & 4.0 & 4.0 & 4.0 & 4.0 & 4.0 & 4.0 & 4.0 & 4.0 & 4.0 & 4.0 & 4.0 & 4.0 & 4.0 \\
\hline $\mathrm{N}$ & 4.0 & 4.0 & 4.0 & 4.0 & 4.0 & 4.0 & 4.0 & 4.0 & 4.0 & 4.0 & 4.0 & 4.0 & 4.0 & 4.0 & 4.0 & 4.0 & 4.0 \\
\hline $\mathrm{O}$ & 7.7 & 4.0 & 4.0 & 7.4 & 4.0 & 7.5 & 7.0 & 7.5 & 9.0 & 4.0 & 8.0 & 8.0 & 7.7 & 8.6 & 7.0 & 8.4 & 4.0 \\
\hline $\mathrm{P}$ & 4.0 & 4.0 & 4.0 & 4.0 & 4.0 & 4.0 & 4.0 & 4.0 & 4.0 & 4.0 & 4.0 & 4.0 & 4.0 & 4.0 & 4.0 & 4.0 & 4.0 \\
\hline Q & 4.0 & 4.0 & 5.3 & 4.0 & 4.0 & 4.0 & 4.0 & 4.0 & 4.0 & 4.0 & 6.1 & 4.0 & 4.0 & 4.0 & 5.7 & 4.0 & 4.0 \\
\hline R & 4.0 & 4.0 & 4.0 & 4.0 & 4.0 & 4.0 & 4.0 & 4.0 & 5.6 & 6.2 & 4.0 & 4.0 & 4.0 & 4.0 & 6.9 & 4.0 & 6.0 \\
\hline $\mathrm{S}$ & 4.0 & 4.0 & 4.0 & 4.0 & 4.0 & 4.0 & 4.0 & 4.0 & 4.0 & 4.0 & 4.0 & 4.0 & 4.0 & 4.0 & 4.0 & 4.0 & 4.0 \\
\hline $\mathrm{T}$ & 4.0 & 4.0 & 4.0 & 4.0 & 4.0 & 4.0 & 4.0 & 4.0 & 4.0 & 4.0 & 4.0 & 4.0 & 4.0 & 4.0 & 4.0 & 4.0 & 4.0 \\
\hline $\mathrm{U}$ & 4.0 & 4.0 & 4.0 & 4.0 & 4.0 & 4.0 & 4.0 & 4.0 & 4.0 & 4.0 & 4.0 & 4.0 & 4.0 & 4.0 & 4.0 & 4.0 & 4.0 \\
\hline V & 4.0 & 4.0 & 4.0 & 4.0 & 4.0 & 4.0 & 4.0 & 9.8 & 4.0 & 4.0 & 6.2 & 4.0 & 7.3 & 4.0 & 4.0 & 8.6 & 4.0 \\
\hline W & 8.4 & 6.7 & 8.0 & 9.2 & 4.0 & 4.0 & 4.0 & 4.0 & 8.8 & 7.8 & 8.0 & 9.2 & 4.0 & 4.0 & 9.3 & 8.0 & $4 .($ \\
\hline$X$ & 4.0 & 4.0 & 4.0 & 4.0 & 4.0 & 4.0 & 4.0 & 10.2 & 4.0 & 6.7 & 4.0 & 4.0 & 4.0 & 4.0 & 4.0 & 4.0 & 4.0 \\
\hline $\mathrm{Y}$ & 8.9 & 4.0 & 4.0 & 4.0 & 4.0 & 4.0 & 4.0 & 4.0 & 4.0 & 4.0 & 4.0 & 4.0 & 4.0 & 4.0 & 4.0 & 4.0 & 4.0 \\
\hline
\end{tabular}

A Acinetobacter calcoacetica; B Aeromonas hydrophila; C Alcaligenes faecalis; D Bacillus subtilis; E Beneckea natriegens; F Brevibacterium linens; G Brocothrix thermosphacta; H Citrobacter freundii; I Clostridium sporogenes; J Enterobacter aerogenes; K Enterococcus faecalis; L Erwinia carotovora; M Escherichia coli; N Flavobacterium suaveolens; O Klebsiella pneumoniae; P Lactobacillus plantarum; Q Leuconostoc cremoris; R Micrococcus luteus; S Moraxella sp.; T Proteus vulgaris; U Pseudomonas aeruginosa; V Salmonella pullorum; W Serratia marcescens; X Staphylococcus aureus; Y Yersinia enterocolitica.

described by different authors. Incorrect identification of compounds, using GC methods and standard comparison, is also possible.

\section{Antibacterial characteristics of volatile oils}

There was a varying response to the volatile oil in terms of antibacterial properties (Table 8). There were clearly some antibacterial constituent(s) present since a number of bacteria showed noticeable growth inhibition, including Acinetobacter cal- coacetica (spoilage organism), Aeromonas hydrophila (an environmental organism found in water courses which can also be a pathogen of fish), Breviobacterium linens (spoilage organism found in soft cheese), Brocothrix thermosphacta (spoilage organism found in pork sausage), Klebsiella pneumoniae (human pathogen) and Serratia marcescens (secondary opportunist pathogen). There is no obvious explanation as to why hyssop plants of different geographical origin gave strong inhibition against some bacteria but not others, and equally, why certain bacteria were only susceptible 
to a number of hyssop volatile oils: the chemical analysis of the oils did not reveal wide variation in the components present.
Acknowledgements. SAC Auchincruive receives funding from the Scottich Office of Agriculture and Fisheries Department. The authors thank the staff of the research station and Elizabeth Eaglesham for excellent technical assistance.

\section{References}

BonaR, A. 1985. Herbs. Complete guide of cultivation and use. 144 p. Hamlyn. London.

BSI 1985. British standard methods of test for species and condiments. Determination of volatile oil content. BS 4585 Part 15. ISO 6571-1984.

Deans, S. G. \& Ritchie, G. A. 1987. Antibacterial properties of plant essential oils. Int. J. Food Microbiology 5: 165180.

FleisCher, A. \& Fleischer, Z. 1988. Identification of biblical hyssop and origin of the traditional use of oregano group herbs in the Mediterranean region. Econ. Botany 42: 232-241.

Galambosi, B., Holm, Y. \& Sz-Galambosi, ZS. 1989. Yield and volatile oil of four perennial herbs grown in Finland. Abstracts of the 20th international symposium on essential oils, Würzburg, Germany.

—, Kaukovirta, E. \& Sz-Galambosi, ZS. 1991. Cultivation of spices and medicinal herbs. University of Helsinki, Department of Horticulture, Publ. No. 18. 104 p. Helsinki.

Genders, S. 1980. Growing herbs. 168 p. Hodder and Stoughton.

Hay, R. K. M., Svoboda, K. P. \& Barr, D. 1988. Physiological problems in the development of essential oil crops. Crop Research 28: 35-45.

Hilal, S. H., El-Alfy, T. S. \& Elsherei, M. M. 1978. Investigation of the volatile oil of Hyssopus officinalis L. Egypt. J. Pharm. Sci. 19: 177-184.

HOOPER, M. 1984. Herbs and medicinal plants. 125 p. Kingfisher, London.

Joulain, D. \& Ragault, M. 1976. Some new constituents of the essential oil of Hyssopus officinalis. Riv. Ital. Essenze, Profumi, Piante Off., Aromi, Saponi, Cosmet, Aerosol 58: 129131.

KAPELEV, I. G. 1986. Introduction of hyssop. Maslichenye Kultury 1: 37-38.

Khodzhimatov, K. \& Ramazanova, N. 1975. Certain biological characteristics and changes in the content and composition of the essential oils of Hyssopus officinalis grown in Taskent. Rastit. Resur. 11: 238-242.

Lawrence, B. 1980. Progress in essential oils. Perfum Flavor 5, 6: 27-32.

- 1984. Progress in essential oils. Perfum Flavor 9: 35-45.
Mechraz, R., Pesevski, N., Apostolova, B., Mermerska, E., Filipov, Z. \& Vlkanova, G. 1989. A study on experimentally created mutant of Hyssopus officinalis. Plant Science 26: 47-49.

SANECKI, K. I. 1985. The book of herbs. 127 p. Quintet, London.

Schultz, G. \& Stahl-Biskup, E. 1991. Essential oils and glycosidic bound volatiles from leaves, stems, flowers and roots of Hyssopus officinalis L. Flav. Frag. J. 6: 69-73.

Simon, J. E., Chadwick, A. F. \& Craker, L. E. 1984. Herbs. An indexed bibliography 1971-1980. Archon Books. p. 50-51.

Steinmetz, M. D., Tognetti, P., Mourgue, M., Jouglard, J. \& Millet, Y. 1980. Sur la toxicite de certaines huiles essentielles du commerce: essence d'hyopse et essence de sauge. Plant Med Phytother 14, 1: 34-35.

Svoboda, K. P., Hay, R. K. M. \& Waterman, P. G. 1990. The growth and volatile oil yield of summer savory (Satureja hortensis) in a cool wet environment. J. Hort. Sci. 65: 659-665.

Timcuk, K. C., Celovskaja, L. N. \& Popov, J. C. 1986. Hyssopus officinalis - a promising volatile oil crop. Izv. Akad. Nauk Moldavskoj SSR, Biolog. i Chimic. Nauk 4: 53-57.

\section{Manuscript received September 1993}

Bertalan Galambosi

Agricultural Research Centre of Finland

South Savo Research Station

FIN-50600 Mikkeli, Finland

Katerina P. Svoboda

Stanley G. Deans

Aromatic and Medicinal Plant Group

Scottish Agricultural College,

Auchincruive AYR KA6 5HW

Scotland, United Kingdom

Eva Hethelyi

Research Institute for Medicinal Plants H-2011 Budakalasz, Hungary 


\title{
SELOSTUS
}

\section{Eri iisoppilajikkeiden agronomiset ja fytokemialliset ominaisuudet}

\author{
Bertalan Galambosi, Katerina P. Svoboda, Stanley G. Deans ja \\ EVA HETHEL
}

Maatalouden tutkimuskeskus, Scottish Agricultural College ja Research Institute for Medicinal Plants

Mikkelissä tutkittiin 13 eri alkuperää olevaa iisoppilajia vuosina 1990-1992. Siemeniä saatiin Unkarista, Romaniasta, Sveitsistä, Englannista (3) ja Suomesta (7). Iisoppilajeista tutkittiin yksi-, kaksi- ja kolmivuotisten kasvien kukkien väriä, tuore- ja kuivasatoa sekä siementuotantoa.

Kasvien korkeus ja satoisuus vaihteli iästä ja lajikkeesta riippuen. Matalin $(42-47 \mathrm{~cm})$ ja heikkosatoisin $\left(0,5 \mathrm{~kg} / \mathrm{m}^{2}\right)$ oli romanialainen punavärinen lajike. Korkeimpia ja satoisimpia olivat Englannista saadut valkoinen ja vaaleanpunainen lajike sekä sveitsiläinen alalaji aristatus. Niiden korkeus täyskukinnossa oli $65-75 \mathrm{~cm}$ ja tuoresato $3,0-3,2 \mathrm{~kg} / \mathrm{m}^{2}$. Tuoresadon kuiva-ainepitoisuus oli $22-26 \%$ ja lehti-varsi suhde $1: 1$. Tuoresadosta saatiin 10-14 \% kuivaa myyntikelpoista lehtisatoa. Kaikki lajikkeet tuottivat hyvälaatuista siementä, ja siementen itävyys oli kolmen vuoden keskiarvona $87 \%$.
Edellä mainituista ja Skotlannissa kolmena vuonna kasvatetuista ranskalaisista lajikkeista selvitettiin myös haihtuvan öljyn määrä, koostumus ja antibakteerinen vaikutus. Suomalainen ja skotlantilainen iisoppiöljy olivat hyvälaatuisia. Haihtuvan öljyn määrä vaihteli 0,4-1,4\% kuiva-ainesadosta. Skotlannissa lajikkeiden välillä oli melko suurta vaihtelua. Suomessa siniset ja sekaväriset iisopit sisälsivät öljyä $0,7-1,3 \%$ ja punaiset ja valkoiset $0,6-0,8 \%$.

Iisoppiöljyn vaikutukset 25 bakteeria vastaan olivat vaihtelevia ja lisätutkimuksia tarvitaan antibakteeristen vaikutusten selvittämiseksi. Iisoppi osoittautui kokeissa talvenkestäväksi kasviksi, joka monivuotisenakin tuottaa hyvälaatuista öljyä Skotlannissa ja Suomessa. 